\title{
Consumer Expectation from Online Retailers in Developing E-commerce Market: An Investigation of Generation Y in Bangladesh
}

\author{
Syed Mahmudur Rahman ${ }^{1}$ \\ ${ }^{1}$ BRAC Business School, BRAC University, Dhaka, Bangladesh \\ Correspondence: Syed Mahmudur Rahman, BRAC Business School, BRAC University, Dhaka, Bangladesh. \\ E-mail: syed.ma.rahman@gmail.com
}

Received: June 1, 2015

doi:10.5539/ibr.v8n7p121
Accepted: June 15, 2015

Online Published: June 25, 2015

URL: http://dx.doi.org/10.5539/ibr.v8n7p121

\begin{abstract}
This paper aims to investigate the expectation from online retailers in the context of Generation $Y$, as the target market group in Bangladesh. It also examines the similarities and dissimilarities between the global online retail market trend and the target group. Volunteer final year university students conducted face to face survey using structured questionnaires. Primary data was collected using paper-and-pencil method where interviewee completed the form in most of the cases. This research found differences between the expectations of consumers from online retailers and the online market trend in developed countries. Existing issues and directions for future online businesses have been discussed. Most of the males want to purchase 'Clothing and footwear' online, whereas 'Jewelleries and Watches' is the most desired online product category by females. Two third of Gen Y in Bangladesh is already shopping online with high interest in F-commerce. Online shopping abandon rate is high due to service quality issue. Lowering internet cost is driving the e-commerce growth. $450 \mathrm{Gen} \mathrm{Y}$ respondents living in the capital have been surveyed, where internet service is optimum. Larger population from different age groups with different backgrounds, living in different cities can be examined in future. Need for reliable delivery service to support e-commerce growth, cash on delivery options, addition of Skype and Viber in customer service and success stories of Facebook stores have been revealed for the consideration of the existing and future market entrants. The findings should work as a guide for the international investors and MNCs. This study is the first of its kind in the context of Bangladesh and sets a benchmark. This research opens the door for continuous evaluation of the market and to venture new business and services as per consumer expectations.
\end{abstract}

Keywords: E-commerce, E-business, online consumer behaviour, generation Y, Bangladesh

\section{Introduction}

As the online market in the developed countries have matured over the past decade, developing countries like Bangladesh is pursuing the upward trend in much faster pace (Robenhagen, Shahrukh, \& Taufiq, 2014). Consumer willingness to try online services (Al Noor \& Arif, 2011), strategic government initiative of 'Digital Bangladesh by 2021' (a2i, 2009), local and foreign investment from the private sectors (Garza, 2015; WorldBank, 2014) and the growth of the ICT sector (Bank, 2015; KPMG, 2012; Nyenrode, 2014; Robenhagen et al., 2014) are fuelling the rapid growth of e-business and e-commerce in Bangladesh. Recent report by GSMA Intelligence dubbed the growth of mobile access in Bangladesh as 'well ahead of time' (Lucini \& Hatt, 2014). Although 98\% mobile connections were $2 \mathrm{G}$ and only $6 \%$ subscribers were using smartphones at the time of the this GSMA research (2014), mobile data usage was accounting for $20 \%$ of total internet usage. This scenario is a clear indication of the consumer intention to use internet services, thus much faster $3 \mathrm{G}$ internet access, introduced in late 2013, is expected to take over $2 \mathrm{G}$ internet usage by 2020 (Lucini \& Hatt, 2014). Developed online markets are observing a surge in E-commerce and $\mathrm{M}$-commerce facilitated by faster internet access and availability of smartphone (Einav, Levin, Popov, \& Sundaresan, 2014). Despite a late start, the rapidly developing online market in Bangladesh is poised to catch-up with developed online markets in the coming years.

Bangladesh has a much younger population with $32.3 \%$ below the age of 14 years, $18.8 \%$ between the ages of 15-24 and only $11 \%$ above 55 years of age (CIA, 2014). Similar demography has proven to be the key driver of e-commerce growth in other countries in the region and beyond (Ahmad \& Agrawal, 2014; Badran, 2013; Deshmukh, Deshmukh, \& Thampi, 2013; Mata \& Quesada, 2014; Sharma \& Mishra, 2012), but at the same time marketers are finding it challenging to meet the expectations of these young minds (B. Valentine \& L. Powers, 
2013; Lazarevic, 2012). Although few researchers have started to examine the state of e-commerce in Bangladesh over the past few years, there is a gap in market research to learn the expectations of the consumers from online retailers. This study aims to be the first of its kind investigating the current online purchase behaviour of Generation Y in Bangladesh with the intention to receive future directions from the demography. In the short to medium term the outcome of this research should pave the ways of new entrepreneurships and the application should help existing online businesses operating in Bangladesh to realign their strategy with consumer demand. In the long-term the effort of online retailers will create a much desired online purchasing experience for the next generation of buyers which will be the key to achieve a sustainable growth.

This article starts with the detailed research statement and a review of current literatures on the evolution of e-commerce in Bangladesh and Generation Y consumer behaviour. The methodology section explains the process of developing questionnaire to compare the expectations of the target group with the global online retail trend. This section also describes the primary data collection process. The findings of the survey are presented in the following section. Lastly a detailed examination of the results followed by practical implications and further research recommendations is provided.

\section{Research Statement and Purpose}

E-commerce i.e. E-business, online business, internet business is not new in Bangladesh but market started to develop rapidly in recent years due to huge consumer interest. Leading local online job portal Bdjobs.com registered in 2000, popular news portal in Bengali language Prothom-alo.com is operating since 2001 and the popular English newspaper TheDailyStar.com followed the online trend in 2002 (WHOis.net, 2015). Most of these early websites were non-transactional and the opportunity to show static advertisements online as a value-added service to their existing clients was the core reason to initiate e-version. Transactional e-commerce sites started to enter online market in Bangladesh in 2004-2006 period with the launch of online marketplace CellBazaar.com, online gift delivery service UpoharBd.com etc. (WHOis.net, 2015). But the market started to develop sharply in 2011-2012 period with the help of foreign investment in Bikroy.com (Nyenrode, 2014; WHOis.net, 2015), transformation of early entrant CellBazaar.com to Ekhanei.com as a competitor of Bikroy.com and the entry of Rocket Internet to operate online businesses such as FoodPanda.com.bd for online food order and home delivery with cash on delivery option, Kaymu.com.bd as online marketplace and property website Lamudi.com.bd. While these medium to large size multinational companies were expanding their operations in Bangladesh, individual entrepreneurs started to buy and sell using the social group and brand pages in Facebook.com, which tops the web traffic chart in Bangladesh (Alexa, 2015). Starting a business on Facebook is much more convenient than opening and operating a .com or .com.bd website which requires fund. Pre-research conversation with young university students in mid-2014 found an existing and growing trend towards Facebook shopping in Bangladesh as the traditional online shops are not providing all the products that they are expecting. Research in developed online market supports this trend and found that co-creation value, social value and usage intensity influence consumer engagement with social media brand pages (De Vries \& Carlson, 2014).

Market gap created by the expectations of online consumers and the offerings from the existing online retailers increase the demand for this research. The online market in Bangladesh will grow along with the current young population and firms should examine their demand and customize their offerings accordingly. As more and more international investors are coming onshore, there is a degree of chance that some will take canned decision to replicate a successful business model working in a developed online market instead of taking the advantages of co-creation (Witell, Kristensson, Gustafsson, \& Löfgren, 2011). One example can be the number of online Grocery store operating delivery services in the capital city Dhaka despite the example of failure and considering the traditional grocery shopping habit in Bangladesh (Fisher \& Kotha, 2014; Laan, 2015; Navis, Fisher, Raffaelli, Glynn, \& Watkiss, 2012)! The purpose of this research is to find answers to the following questions and to set a benchmark for online market research:

1) What is the current online behaviour of Generation $Y$ in Bangladesh?

2) Which product categories are expected by Gen $Y$ on online stores in Bangladesh?

3) Which product categories are not so desired on online stores?

4) Similarities and dissimilarities with global online purchase trend.

5) Online shopping abandon rate and reasons behind it.

This study is concentrated on buy/sell online retail market and not evaluated on other online services such as online banking and bill payment. 


\section{Literature Review}

\subsection{Co-Creating Products and Services: A Gen Y Trend}

Each decade Generation Y (Gen Y) (also known as Millennial Generation, Millennials, Echo Boomers, Why Generation, Net Generation, Gen Wired, iPod Generation, We Generation, DotNet, Ne(x)t Generation, Nexters, First Globals) (Ordun, 2015), pass a transition from one phase to another, with its common age group remaining the same, enumerated between 20-35 years (Aksoy et al., 2013). A person born between 1981 and 1995 is considered as Gen Y in this research following the settings in similar recent researches (Aksoy et al., 2013; Zhang, Carpenter, \& Brosdahl, 2011). Currently, they are deemed to be the prime online consumer group (Ordun, 2015) and Bangladesh has a much younger population (CIA, 2014), therefore studying their purchase behaviour is important.

Traits of Gen $\mathrm{Y}$ is a highly researchable area which has been significantly attracting researchers for years, due to its rapidly evolving nature influenced by rapid globalization of information (Reynolds, Bush, \& Geist, 2008). Unlike their predecessors who were taking cautious steps while recovering from damages made by wars and the great depression (Sisson \& Rose, 1991), this generation started to benefit from the wealth that they inherited. They watched iPhone to revolutionize mobile technology and communication media (Wei, 2012) and experienced the journey of social media such as Facebook only to become addicted in no time (Cabral, 2011). The innovations provide them with a continual source of knowledge and entertainment, besides a new ecosystem for their social lives. They also tend to be the emblem of generation-based identity. Thus these digital troops of either students or relatively recent entrants to the workforce are expected to be technologically savvy (Aksoy et al., 2013). They went through the learning curve of social media interaction on their own accord and learnt to value others' opinions (Palfrey \& Gasser, 2013). To the benefits of the businesses and marketers, Gen Y follows a participatory culture (eMarketer, 2011) and feel important when they provide feedback about the brands to co-create products and services that they use (De Vries \& Carlson, 2014; Heidenreich \& Handrich, 2015; Randall $\&$ Bhalla, 2014). This attribute affirms the need for this research to recognize the expectation of Gen $\mathrm{Y}$ to develop a much desired online market in Bangladesh.

\subsection{IT and E-Commerce in Bangladesh: A Trending Factor}

The business of commercial transactions between and among organizations and individuals using the aid of digital technologies is commonly regarded as E-commerce (Chaffey, 2007). Initiating since 1995, e-commerce, (also called electronic commerce) has continued to receive proliferated growth rates of over $100 \%$ in a year at the early days of Amazon.com (Laudon \& Traver, 2007). Till date, Amazon.com serves as one of the most prominent and successful online retail stores which has had a transformational impact on e-commerce worldwide, serving as an epitome. Their recent announcement of US \$2 billion investment in neighbouring India accentuates the opportunities or online businesses in South Asian region (Forbs, 2014).

In 2005, the overall Internet and e-commerce adoption rate was lower in South Asia than the rest of the world (Kshetri \& Dholakia, 2005). However, a change in this trail took place in the past 10 years with the number of Internet users and thus, the number of people engaging in e-business of various sorts increasing at a rapid pace (Abbasi, Chandio, Soomro, \& Shah, 2011). Recent McKinsey report (2014) estimates that the number of global Internet users shall be between 500-900 million by 2017 and this specifically includes some of the South Asian countries, with Bangladesh as one of the highlights. This outcome echoes previous KPMG (2012) report on the growth of IT sector in Bangladesh, especially since the year 2010 when its freelancer community contributed around US $\$ 700$ million towards exports. This has led to Bangladesh being visibly consistent in top freelance work locations on sites such as oDesk, eLance, to name a few.

The usage of mobile internet is a key contributing aspect towards the prevalence of e-commerce in Bangladesh. Following Table 1, 2 and 3 show the falling bandwidth costs in Bangladesh, cost of mobile data for major mobile operators in Bangladesh and a mobile data price comparison with countries with developed e-commerce market. Though the percentage of total Internet users in Bangladesh has been deemed to be low compared to some other countries (Khan, Hossain, Hasan, \& Clement, 2012), the online population is rising due to falling cost of Internet bandwidth. In early 2015, BTCL-the governing body of Tele-communication in Bangladesh, decided to cut down bandwidth prices by further 33\% in next year. Complementing that, Bangladesh has approximately 36.50 million internet users (M. Z. Islam, 2014) along with a high mobile penetration due to low costs and low calling charges. 
Table 1. Cost of per Mbps bandwidth in Bangladesh

\begin{tabular}{|c|c|c|c|c|c|c|c|}
\hline & Year & $2006-2007$ & 2008-2009 & 2011-2012 & 2013 & 2014 & 2015 \\
\hline $\begin{array}{l}\text { Per Mbps } \\
\text { BDT (ד) }\end{array}$ & $\begin{array}{l}\text { Bandwidth cost in } \\
\text { (Note } 1,2,3 \text { ) }\end{array}$ & ఫ127,000 - ఫ75,000 & ఫ28,000 - ₹ 17,400 & ఫ 12,000 - ఫ 8,000 & ₹4,800 & t 2,800 & t2,280 \\
\hline
\end{tabular}

Table 1. Rate of 1GB mobile data in Bangladesh (May 2015)

\begin{tabular}{|c|c|c|c|c|c|}
\hline Operators & Airtel & Grameenphone & Teletalk & Robi & Banglalink \\
\hline Internet Cost /1GB (BDT), Exc. VAT & Ł299 (Note 4) & ఫ275 (Note 5) & Z260 (Note 6) & Z275 (Note 7) & ఫ275 (Note 8) \\
\hline
\end{tabular}

Table 2. Comparison of mobile data with other countries (May 2015)

\begin{tabular}{|c|c|c|c|c|}
\hline Country & UK & USA & Australia & India \\
\hline Cost/1GB & GB $£ 10$ (Note 9) & US $\$ 10$ (Note 10$)$ & AU $\$ 10$ (Note 11$)$ & IN $\square 155$ - $\square 252$ (Note 12 ) \\
\hline Approximate in BDT (飞) & †े 1,188.37 & 七778.37 & ఫ5595.79 & ఫ 189.42 - ๖307.95 \\
\hline
\end{tabular}

\subsubsection{Online Payment Process}

Online payment methods, reliability of payment gateways and availability of credit card are barriers to the growth of e-commerce, especially in the developing countries such as India and Bangladesh where credit system is very much closed (Bhattacharya \& Mishra, 2015). Besides the growth of Internet, Mobile Communication, which has given rise to M-commerce, is one of the rapidly growing industries in the $21^{\text {st }}$ century. Early day's researchers in Bangladeshi e-commerce contributed to understand the factors affecting the adoption of m-commerce in a developing market (M. A. Islam, Khan, Ramayah, \& Hossain, 2011). Government and private sectors invested in the development of m-commerce in Bangladesh to help create success stories such as bKash in very short time (Chen \& Rasmussen, 2014). bKash tends to be the pioneer and fastest growing mobile banking service provider in Bangladesh (Hasan \& Islam, 2013) with 22\% of adult population as its customer in 2013 (Chen \& Rasmussen, 2014; Priyo et al., 2015). Besides bKash, a new venture named Union Digital Centres (UDC), has taken an initiative to e-government services to the rural people. This has opened new doorways to the fact that mobile banking and mobile payment shall grow to be more widespread in the nation, engaging a wider rural base (Faroqi, 2015). The growing popularity and convenience of online and mobile payment will complement the overall growth of e-commerce in Bangladesh.

\subsubsection{Market Potential and Challenges}

Regardless of the huge market potential, challenges still remain. McKinsey's (2014) report highlights the fact that globally approximately 1.1-2.8 billion people do not get the privileges of the online world due to lack of adequate mobile network coverage, and Bangladesh is a part of the statistics of the disadvantaged. Further issues such as inadequate infrastructure, lack of digital literacy, low purchasing power, are some of the conspicuous challenges in developing countries like Bangladesh. Bangladesh falls within countries with high barriers and holds an index of 28 in this category (WorldBank, 2014). Nevertheless, the market potential continues to remain promising in various aspects, including GDP growth, as the information and statistics in the aforementioned parts portray (WorldBank, 2014). Also, Bangladesh is trying to establish itself as 'Digital Bangladesh' by 2021 (a2i, 2009) and therefore, growth of the online population is mandatory to attain this objective (Faroqi, 2015).

\subsubsection{E-Commerce Fair and E-Commerce Education}

E-commerce Fair (e-commercefair.com) organized by Computer Jagat which is the pioneer ICT publication in Bangladesh has contributed to the growth of e-commerce in Bangladesh at the root level. The capital city Dhaka is the primary location of the fair and it had its $5^{\text {th }}$ fair in 2014. Their effort to promote e-commerce in Bangladesh to the foreign investors through their events in London, UK is a much welcome initiative. Recently the organization has started to have fair in other major cities such as Chittagong and Sylhet. This decentralization of e-commerce from capital to other cities is expected to work as a catalyst to promote growth in the sector. The organization also composed the first ever e-commerce directory of Bangladesh to enlist most local online business to date (ComJagat, 2014). 
Along with business initiatives, private universities such as BRAC University in Bangladesh have started to offer e-business concentrated subjects as a part of their Bachelor of Business Administration (BBA) program. Structured learning will help the next wave of leaders to take the e-commerce industry in Bangladesh to a new level with informed decision making skills.

\section{Methodology}

\subsection{Study Design}

Young university students and graduates within the age limit of 20 to 25 are part of Gen Y. This demanding group is regularly utilized by researchers and corporations to develop product in a consumer controlled market (Chu \& Choi, 2011; Mangold \& Faulds, 2009). As the target group is young adults, self-administered paper-and-pencil intercept survey deemed appropriate for the purpose of this research (De Vries \& Carlson, 2014). It is logical to observe variation in expectation in different gender and age cluster (age between 20-25 or 25-30) within Gen Y (Bakewell \& Mitchell, 2003; Noble, Haytko, \& Phillips, 2009) due to their working and earning status. Thus data from various age clusters were required to avoid biasness in their outcome. Final year students at BRAC University volunteered for the survey. Initial screening found their birth year is between 1991 and 1994. This age cluster of 21-24 years (middle aged Gen-Y) are students with no or part-time job. The same group of volunteers assisted to collect self-administrated survey from their elder family members and friends born between 1980 and 1995. They are 25 to 35 years old and most of them are working full time or engaged in business activities. All volunteers have good English reading and writing skill to administer a survey.

Every year PricewaterhouseCoopers LLP (PwC) conducts their 'Total Retail' survey across 19 developed online markets to observe the consumer trend. The survey question was prepared according to the top 11 product categories found in PwC survey (PwC, 2015). This process of categorizing is suitable for consumer research (Spiggle, 1994) and the options in the questionnaire were randomly shuffled to avoid any kind of biasness. 'Fast Food/Lunch/Dinner' was added in the survey as the $12^{\text {th }}$ category as there are multiple service providers currently operating in Bangladesh. Such service can be compared to Pizza Hut home delivery available in Australia, USA, etc. This research aims to find the demand of a product category on online stores, a service or an option; thus most questions were prepared to be suitable for frequency analysis using SPSS version 17. The survey questionnaire was designed by keeping the recent trends of the target population in mind to facilitate co-creation (De Vries \& Carlson, 2014; Witell et al., 2011) and consisted of 11 quantitative and 4 qualitative questions. Two major questions requested the respondents to rank their top 5 ( 1 being the most strong and 5 being the least strong) expected or not so expected product categories respectively, that they wish to purchase online. Other expectations which were not available in the pre-selected list were asked to the respondents through an open ended question. All volunteers received adequate information on each product categories so that any question from the participant can be answered. The survey also included questions about their general view on online shopping in Bangladesh. Preparation for this research started in late- 2014 and data collection was conducted in May, 2015.

\subsection{Sample Profile}

In total, 462 completed surveys were collected and 438 were usable for data entry after initial screening. 424 usable samples remained after further screening to include only Gen Y, age group 20-35, in the analysis. Of this final sample, 58.3\% were male and $41.5 \%$ were female. Within Gen Y, 262 were aged between 20 to 25 years, 120 were aged between 26 to 30 years and 42 were aged between 31 and 35 years; meaning a higher number of young Gen Y in the sample. 326 respondents were final year university students, a Bachelors degree is the highest education of 49 people and 47 respondents have completed their post-graduation (Masters) degree.

\section{Results and Discussions}

\subsection{Current Online Behaviour of Gen Y in Bangladesh}

\subsubsection{Two Third of Gen Y Population Is Already Shopping Online Regardless Their Gender}

All 424 respondents within the target age group of 20-35 years answered to the Yes/No question of online shopping. Among them 247 (58.3\%) were male and 177 (41.5\%) were female. Total 281 (66.3\%) participants have already shopped online and only one-third of the surveyed population (143 people, 33.7\%) has not done any online shopping at the time of the data collection. Total 262 respondents were from the age group of 20-25 years and $68.3 \%$ (176) have shopped online. On the other hand 63.5\% (129 out of 203) people in the higher age group of 26-35 have already shopped online. The number of non-online shopper is higher in the higher age group, $36.5 \%$ compared to $31.7 \%$ in $20-25$ years of age group. This ratio supports an argument that upcoming credit holders in Bangladesh are more perceived towards online shopping. In terms of gender, more male (37.1\%) are 
shopping compared to female (29.1\%). SPSS was used to test the relationship between the online shopping tendency of male and female; $H_{0}=$ There is no relationship between gender and online shopping status (Yes/No). Failed to reject null hypotheses at 5\% significance level as Pearson Chi-square p-value of $1.836(\mathrm{~N}=423)$ is greater than 0.05 . Therefore statistically there is no relationship between someone's gender and online shopping status. The outcome also shows that more male (37.1\%) are shopping online than female (29.1\%).

\subsubsection{Consumers Prefer English as the Primary Language of the Shopping Sites}

410 out of 424 respondents expressed their language preference on a website. $85.4 \%$ wants to see product and service description on the websites in English compared to only 11.3\% (48 people) prefer Bengali. This is an important outcome considering English is the second language in Bangladesh. Recent research in Arabic speaking country identifies the use of native language in websites as one of the key success factors in e-commerce (Al-Sedrani \& Al-Khalifa, 2012) which asks for more explanation of the finding in this research. Discussions with some respondents revel their wish for both Bengali and English language on the website to facilitate understanding. They believe having the option to switch to native language helps the brand to relate to the consumers.

\subsubsection{Online Traffic Should Grow as Kids Start to Learn Computer at Younger Age}

One-third of the respondent claimed to start using computer at the age of 10 or earlier. In this survey, the median age to start using computer is 13 . The relationship between respondent's current status of online shopping and their age to start using computer gives a hypothesis $H_{0}=$ There is no relationship between early exposure to computer and doing shopping online. Chi-Square test outcome from SPSS at 5\% significance level provides Pearson Chi-square p-value of $41.27(\mathrm{~N}=402)$ which is greater than 0.05 . Therefore statistically there is no relationship between the age when a respondent started to use computer and his/her interest to shop online. However, latest American children's media use report shows that $75 \%$ of all kids under the age of 2 have access to 'smart' device which is taking them online in much younger age (Rideout, 2013) compared to 52\% back in 2011. This sharp growth is contributed by the falling price of technology and increased affordability of the parents (Rideout, 2013). Smartphone and 3G internet connections have recently started to rollout in Bangladesh (Lucini \& Hatt, 2014). The rise in online traffic will be expected in future as the population starts to become computer, internet and social media literate at much younger age (Roberts \& Foehr, 2008).

\subsubsection{Social Media Access Is the Primary Reason to Use Internet}

419 interviewees revealed their reasons for using internet. $51.2 \%$, which is more than half of the internet population, uses internet primarily to access Facebook. Using internet for education purpose ranked second in the priority list among 90 respondents $(21.2 \%)$; it was expected from this research population as most of them are studying at university. However, internet is influencing young people to study (Selwyn, 2012) and the need for low cost internet coverage across the country is evident to promote quality education. Third in the priority list is watching video on YouTube (57 people, 13.4\%) and followed by $50(11.8 \%)$ respondents prioritized reading free online newspaper. Most of the people use portable devices to access internet and social media; $30.2 \%$ uses laptop and $26.2 \%$ uses mobile phone.

\subsubsection{Facebook Is the Most Popular Social Media}

Out of 424 respondents within the age range of 20 to 35, 412 answered the question regarding their Facebook activeness. 377 respondents actively use Facebook and only 8.3\% (35 people) do not use Facebook actively. The age of the 21 non-Facebook users out of 35 users are 25 years and above, meaning social media is much popular with the younger age cluster of Gen Y, which is in line with what Duggan and Brenner (2013) found in their US study. The senior cluster of 25-30 and 30-35 years are either not so keen for the social media experience or they have stopped using it actively to have a work-life balance. Social media is a popular means of online advertisement and the reason for not using social media needs to be investigated further to identify sociocultural influences (Ryan \& Xenos, 2011).

409 respondents answered to the question regarding their use of Twitter, Instagram and Pinterest. $70 \%$ (296) of the population do not use Twitter, 60\% (258) do not use Instagram, and 87\% (354) do not use Pinterest. Most Instagram user uses this media due to its integration with Facebook. Out of the total user group of Instagram, more are male than female (90 vs 60 ), which is opposite to the findings of recent US research (Duggan \& Brenner, 2013). The same research highlights that number of Twitter user doubled since 2010 but the user base is low in Bangladesh. Future research can observe any change in this trend.

\subsubsection{Trend of Having Low Call Credit but Good Data Package for Internet Access}

410 participants responded to Skype and Viber usage. $71 \%$ of the users' actively use Skype and about $73 \%$ uses 
Viber for regular communication with their friends. The statistics also reveals that most of the users who use Skype also use Viber. It is primarily because this user group has mobile data enabled. Discussion with the respondents explains their reason for adopting such communication strategy. Having data package in their mobile enables them to use both Facebook i.e. social media on their handheld device or to use the hotspot of the mobile phone in their laptop to access internet while they are at university or out of home. It also enables them to use free voice and text over internet solutions such as Skype and Viber to communicate with friends with similar interest. Using talk time credit is not logical to them and they prefer to purchase better mobile internet package than having call credit in their phone. They also expect their parents and anyone in need to communicate with them to call them. Few female respondent use this technique also to conceal their mobile phone number as communication using Skype do not make the phone number public.

\subsubsection{Facebook Stores and Kaymu.Com.Bd Are Two Most Popular Shopping Destinations}

The survey found that Facebook stores are most popular among Gen Y followed by Kaymu.com.bd in Bangladesh at the time of this research. It is noticeable that more female are shopping at Facebook stores than male, but an opposite scenario is evident in case of Kaymu.com.bd, Bikroy.com and Rokomari.com. They shop on both Brand's Facebook stores (BFP) managed by firms or individuals and in closed or open Community Facebook Groups (CFG); this practice has recently started to attract the interest of online consumer behaviour researchers (De Vries \& Carlson, 2014; Karnik, Oakley, Venkatanathan, Spiliotopoulos, \& Nisi, 2013; Wang, Woo, Quek, Yang, \& Liu, 2012). The reason for Facebook shopping platform being so popular is possibly because photos on Facebook and texts in comments help emotions to flow via indirect communication media (Kramer, 2012) and emotion increases shopping satisfaction in both men and women (Herter, dos Santos, \& Costa, 2015).

Another surprising outcome is the popularity of Amazon.com and ebay.com despite they are not officially operating in Bangladesh. Discussion with the respondents revealed that Amazon.com and ebay.com are popular due to their huge range of variety and availability of products which are not available through other online stores that are currently operating in Bangladesh. In most cases consumers are choosing the product and requesting their friends and family living overseas to purchase the product locally in Australia, Canada, India, US and UK to ship it to Bangladesh, or to bring it with them while travelling to Bangladesh. This practice highlights the willingness of the Gen Y consumer group to take unconventional and sometimes more costly approach to own a preferred product. This finding reiterates the importance of this research to identify the expected product range of Gen Y consumers from local online retailers.

The outcome also shows the popularity of food delivery services such as foodpanda.com.bd and hungrynaki.com. Both classified sites, bikroy.com and ekhanei.com, are used by the target group but bikroy.com is the most popular. All the websites in top 10 are well advertised through offline and online channels. The list of top sites by user preference does not have any surprise entry and it calls for more advertisement to inform consumers. New market entrants with good advertisement plan should attract more customers and help grow the online market.

Table 4. Popular online shopping sites

\begin{tabular}{|c|c|c|c|}
\hline \multirow{2}{*}{ Website used } & \multicolumn{2}{|c|}{ Gender } & \multirow{2}{*}{ Total user } \\
\hline & Male & Female & \\
\hline Facebook.com & 23 & 41 & 64 \\
\hline Kaymu.com.bd & 21 & 13 & 34 \\
\hline Bikroy.com & 16 & 9 & 25 \\
\hline Amazon.com & 11 & 5 & 16 \\
\hline Rokomari.com & 13 & 3 & 15 \\
\hline ebay.com & 13 & 1 & 14 \\
\hline Foodpanda.com.bd & 8 & 5 & 13 \\
\hline Akhoni.com & 7 & 4 & 11 \\
\hline Ajkerdeal.com & 4 & 2 & 6 \\
\hline Hungrynaki.com & 5 & 1 & 6 \\
\hline
\end{tabular}




\begin{tabular}{llll}
\hline Esho.com & 5 & 0 & 5 \\
Ekhanei.com & 1 & 3 & 4 \\
Ekhoni.com & 1 & 3 & 4 \\
iferi.com & 4 & 0 & 4 \\
Wristband.com & 4 & 0 & 3 \\
Bipony.com.bd & 3 & 0 & 3 \\
Daraz.com.bd & 2 & 1 & 3 \\
\hline
\end{tabular}

\subsection{Expected Product Categories by Gen Y from Online Retailers}

Table 5 summarizes the product category expectation from online retailers by $422 \mathrm{Gen} \mathrm{Y}$ respondents. They were requested to rank their preferred categories on a scale of 1 to 5 . The analysis is conducted by identifying the total response for each category and ranks them accordingly.

There is a difference between the preference of a male and a female. 'Clothing and footwear' tops the list of common expectation but female are keener to purchase 'Jewellery and watches' online. 322 respondents selected 'Clothing and footwear' in their wish list but it also means that 100 interviewee (422-322) did not select this category at all in their top five. This negative factor is possibly more important to justify categories with lower rank than top five i.e. $422-67=355$, about $85 \%$ of total respondents do not want to purchase grocery online.

The top five categories preferred by both male and female are in the desired list of both male and female separately in different order except the case of 'Sports equipment and outdoor'. This category is the least desired item to be purchased by female but ranked fifth by male population.

'Toys', 'Grocery', 'Do-it-yourself and home improvement' and 'Furniture and homeware' categories are less desired by both male and female when it comes to online shopping in Bangladesh. 'Fast food /Lunch /Dinner' was a special category added in this survey which is not measured by PwC (2015) global survey of online retail choice in developed countries. It appears to be a desired online shopping category by Gen Y in Bangladesh. 'Grocery' is ranked six out of eleven in the global survey (PwC, 2015) but ranked eleven in this survey; current online grocery retailers may need to set their strategy accordingly to align their business with consumer expectations.

Table 5. Expected products from online retailers

\begin{tabular}{llccc}
\hline \multicolumn{5}{c}{ Common expectation } \\
\hline \\
1 & Clothing and footwear & Male & Female & Total Response \\
2 & Fast food/ Lunch/Dinner & 181 & 141 & 322 \\
3 & Books & 156 & 120 & 276 \\
4 & Jewellery and watches & 164 & 98 & 262 \\
5 & Consumer electronics and computers & 95 & 144 & 239 \\
6 & Health and beauty/ cosmetics & 178 & 56 & 234 \\
7 & Sports equipment and outdoor & 39 & 116 & 155 \\
8 & Household appliances & 134 & 16 & 150 \\
9 & Furniture and homeware & 77 & 58 & 135 \\
10 & Toys & 60 & 38 & 98 \\
11 & Grocery & 55 & 33 & 88 \\
12 & Do-it-yourself and home improvement & 42 & 25 & 67 \\
\hline
\end{tabular}




\begin{tabular}{|c|c|c|c|c|}
\hline \multicolumn{5}{|c|}{ Expectation of Male } \\
\hline & & Male & Female & Total Response \\
\hline 1 & Clothing and footwear & 181 & 141 & 322 \\
\hline 2 & Consumer electronics and computers & 178 & 56 & 234 \\
\hline 3 & Books & 164 & 98 & 262 \\
\hline 4 & Fast food/ Lunch/Dinner & 156 & 120 & 276 \\
\hline 5 & Sports equipment and outdoor & 134 & 16 & 150 \\
\hline 6 & Jewellery and watches & 95 & 144 & 239 \\
\hline 7 & Household appliances & 77 & 58 & 135 \\
\hline 8 & Furniture and homeware & 60 & 38 & 98 \\
\hline 9 & Toys & 55 & 33 & 88 \\
\hline 10 & Grocery & 42 & 25 & 67 \\
\hline 11 & Health and beauty/ cosmetics & 39 & 116 & 155 \\
\hline 12 & Do-it-yourself and home improvement & 35 & 27 & 62 \\
\hline \multicolumn{5}{|c|}{ Expectation of Female } \\
\hline & & Male & Female & Total Response \\
\hline 1 & Jewellery and watches & 95 & 144 & 239 \\
\hline 2 & Clothing and footwear & 181 & 141 & 322 \\
\hline 3 & Fast food/ Lunch/Dinner & 156 & 120 & 276 \\
\hline 4 & Health and beauty/ cosmetics & 39 & 116 & 155 \\
\hline 5 & Books & 164 & 98 & 262 \\
\hline 6 & Household appliances & 77 & 58 & 135 \\
\hline 7 & Consumer electronics and computers & 178 & 56 & 234 \\
\hline 8 & Furniture and homeware & 60 & 38 & 98 \\
\hline 9 & Toys & 55 & 33 & 88 \\
\hline 10 & Do-it-yourself and home improvement & 35 & 27 & 62 \\
\hline 11 & Grocery & 42 & 25 & 67 \\
\hline 12 & Sports equipment and outdoor & 134 & 16 & 150 \\
\hline
\end{tabular}

\subsection{Not-So-Expected Product Categories by Gen Y from Online Retailer}

Similar to the question of desired product categories, respondents were requested to rank top five not-so-desired categories. This was to investigate the validity of the outcome of the first question i.e. most expected. In Table 6, a higher response means consumers are less expected to buy such product online.

421 responded to this questions and the outcome supports the findings in the table of expected products categories. 'Groceries', 'Toys', 'Furniture and homeware', 'Household appliances' and 'Health and beauty/ cosmetics' tops the list of undesired items on online shops, which are also at the bottom of the desired product category list. 83 responded not to buy clothing and footwear online which is similar to 100 negative responses in desired list.

Surprisingly 'Grocery' and 'Furniture and Homeware' categories are on the top of the not-so-expected list of both male and female. Recent online market study in neighbouring India found the lack of human interaction and bargain is the reason for some product categories to fail online (Ghosh, 2014). Perhaps online buyers in Bangladesh have similar approach. 
Table 6. Not-so-expected products from online retailers

\begin{tabular}{|c|c|c|c|c|}
\hline \multicolumn{5}{|c|}{ Common not-so-expected categories } \\
\hline & & Male & Female & Total Response \\
\hline 1 & Grocery & 162 & 126 & 288 \\
\hline 2 & Furniture and homeware & 158 & 111 & 269 \\
\hline 3 & Household appliances & 125 & 88 & 213 \\
\hline 4 & Toys & 110 & 99 & 209 \\
\hline 5 & Health and beauty/ cosmetics & 149 & 43 & 192 \\
\hline 6 & Do-it-yourself and home improvement & 102 & 66 & 168 \\
\hline 7 & Sports equipment and outdoor & 56 & 95 & 151 \\
\hline 8 & Consumer electronics and computers & 52 & 89 & 141 \\
\hline 9 & Jewellery and watches & 114 & 21 & 135 \\
\hline 10 & Fast food/Lunch/Dinner & 82 & 48 & 130 \\
\hline 11 & Books & 47 & 50 & 97 \\
\hline 12 & Clothing and footwear & 51 & 32 & 83 \\
\hline \multicolumn{5}{|c|}{ Not-so-expected categories by Male } \\
\hline & & Male & Female & Total Response \\
\hline 1 & Grocery & 162 & 126 & 288 \\
\hline 2 & Furniture and homeware & 158 & 111 & 269 \\
\hline 3 & Health and beauty/ cosmetics & 149 & 43 & 192 \\
\hline 4 & Household appliances & 125 & 88 & 213 \\
\hline 5 & Jewellery and watches & 114 & 21 & 135 \\
\hline 6 & Toys & 110 & 99 & 209 \\
\hline 7 & Do-it-yourself and home improvement & 102 & 66 & 168 \\
\hline 8 & Fast food/Lunch/Dinner & 82 & 48 & 130 \\
\hline 9 & Sports equipment and outdoor & 56 & 95 & 151 \\
\hline 10 & Consumer electronics and computers & 52 & 89 & 141 \\
\hline 11 & Clothing and footwear & 51 & 32 & 83 \\
\hline 12 & Books & 47 & 50 & 97 \\
\hline \multicolumn{5}{|c|}{ Not-so-expected categories by Female } \\
\hline & & Male & Female & Total Response \\
\hline 1 & Grocery & 162 & 126 & 288 \\
\hline 2 & Furniture and homeware & 158 & 111 & 269 \\
\hline 3 & Toys & 110 & 99 & 209 \\
\hline 4 & Sports equipment and outdoor & 56 & 95 & 151 \\
\hline 5 & Consumer electronics and computers & 52 & 89 & 141 \\
\hline 6 & Household appliances & 125 & 88 & 213 \\
\hline 7 & Do-it-yourself and home improvement & 102 & 66 & 168 \\
\hline 8 & Books & 47 & 50 & 97 \\
\hline 9 & Fast food/ Lunch/Dinner & 82 & 48 & 130 \\
\hline 10 & Health and beauty/ cosmetics & 149 & 43 & 192 \\
\hline 11 & Clothing and footwear & 51 & 32 & 83 \\
\hline 12 & Jewellery and watches & 114 & 21 & 135 \\
\hline
\end{tabular}




\subsection{Similarities and Dissimilarities with Global Online Purchase Trend}

Table 7 shows the comparison between the global online retail trend as per PwC (2015) survey in 19 developed online markets and the findings in this investigation of Gen Y consumer choice in Bangladesh. As compared in the above table, possibly, online market in Bangladesh will experience similar trend as global online retail in 'Clothing and footwear', 'Books' and 'Consumer electronics and computers' categories. 'Fast food/ Lunch/Dinner' is not an online category that PwC evaluates but it might be worth to monitor this trend. Foreign and local investors need to be careful about few product categories as differences are evident in this research. These differences can be influenced by the differences in culture, earning level, perceived value of online shopping, feelings of uncertainty or privacy/security issues.

Table 7. Global online purchasing trend vs expectation in Bangladesh

\begin{tabular}{cll}
\hline Rank & \multicolumn{1}{c}{ Global online purchase trend } & \multicolumn{1}{c}{ Expectation of Gen Y in Bangladesh } \\
\hline 1 & Books & Clothing and footwear \\
2 & Clothing and footwear & Fast food/ Lunch/Dinner \\
3 & Consumer electronics and computers & Books \\
4 & Do-it-yourself and home improvement & Jewellery and watches \\
5 & Furniture and homeware & Consumer electronics and computers \\
6 & Grocery & Health and beauty/ cosmetics \\
7 & Health and beauty/ cosmetics & Sports equipment and outdoor \\
8 & Household appliances & Household appliances \\
9 & Jewellery and watches & Furniture and homeware \\
10 & Sports equipment and outdoor & Toys \\
11 & Toys & Grocery \\
12 & & Do-it-yourself and home improvement \\
\hline
\end{tabular}

\subsection{Online Shopping Abandon Rate and Reasons behind It}

This research also tried to find online shopping abandon rate and the outcome is alarming. Staggering $67.8 \%$ (173 out of 215 respondents who shopped online) stopped online shopping after one or two purchases and only $42 \%$ remained loyal to the brand that they shopped from. 57\% (114) stopped online shopping due to 'Product quality issue', 26\% (52) did not return to the online store because 'Product was not as described' and 14.5\% (29) was unhappy with the 'Delay in delivery'. Analysis of abandon rate also shows $12.2 \%$ from Facebook.com, $8.2 \%$ from Kaymu.com.bd, 5.9\% from Bikroy.com (classified), 3.1\% from Foodpanda.com.bd, 2.7\% from Amazon.com, 2.4\% from Akhoni.com and Rokomari.com. At the same time Facebook.com has a customer retention rate of $3.1 \%$ and Kaymu.com.bd has a retention rate of $1.6 \%$. Of course, this analysis has limitations and firms are trying to improve their strategies in a developing market. Care must be taken to ensure that Bangladesh can avoid the e-tailing (online retailing) failures observed in India (Ghosh, 2014). Further analysis into the demises of few Facebook shoppers found product quality as the leading issue, followed by product not as described and delay in delivery. Recommendations based on the findings in this research may assist firms and individuals to improve their products and services to better serve the influx of young online shoppers in Bangladesh.

\section{Recommendations}

Two questions were asked during the survey to draw recommendations from the respondents for the online retailers in Bangladesh. First was to learn the reasons for existing shoppers to go online and the second was to comprehend and recommend for the e-tailers. About $45 \%$ male (105) and 35\% female (82) of total 234 respondents shopped online for the overall convenience, variety of products and to save time. To support that proportion, $12.8 \%$ shopped online because their preferred product was only available online. Surprisingly, $1.3 \%$ (1 male and 2 female) shopped online because they found a cheaper deal. Thus e-tailers should introduce new varieties in their product range. Although categories such as 'Groceries' were ranked low in the most desired list in this survey, such business can be made attractive online by offering niche and hard to source products. 
On the opportunity to provide recommendation to the existing and future online retailers, 'Survey customer opinion' topped the list with $27.4 \%$ (116 out of 423 respondents recommended so). This request resonate the co-creation value of Gen Y discussed earlier. Following this suggestion and outcome of recent researches (De Vries \& Carlson, 2014) that collectivism (sense of belonging) and altruism (enjoyment of helping) increases traffic via online word of mouth (eWoM) (Cheung \& Lee, 2012), brands may try to engage young consumers through social media to voice their expectations and give them the sense of achievement by developing products and services accordingly.

Second, third and fourth recommendations by the consumer group are to 'build trust' ( $19.4 \%$ out of $N=423)$, to 'maintain quality' $(21.3 \%$ out of $\mathrm{N}=423)$ and to 'display proper information' ( $6.6 \%$ out of $\mathrm{N}=423)$ respectively. As discovered earlier, most of the respondents shopped online for the overall convenience and in many cases trust were broken due to poor product quality, delay in delivery and mismatch between product description and the actual product. Trust on the e-tailing brand has been identified as the key success factor by many researches over the years regardless the type of business, size of the market and the culture of the consumer (Eid, 2011; Fang et al., 2014; Weisberg, Te'eni, \& Arman, 2011), thus it is of no wonder that Gen Y consumer in Bangladesh wants to build trusted relationship with the brand where they will repurchase from. Among other recommendations 'cash on delivery' and 'free delivery' and 'strong communication' are noticeable.

Following the traits of Gen Y found in literature review, respondents are not so concerned about the price of the product or the service they receive. Only few shopped online to enjoy cheaper deal and only 1 female respondent suggested to offer lower price online than in physical store. The high abandon rate of online shopper found in this research can be due to the self-inflicted strategy of the firms to offer cheaper deal to the consumer at any cost. Maintenance and continuous improvement of product and services attract fund which needs to be covered by either investment or profit. Cutting price to the bone may leave narrow room for profit which ultimately may hurt service quality. Thus firms need to be cautious about their pricing strategy because their premium consumer is looking for convenience through better product and service, not by saving money.

Investors and entrepreneurs may analyse the findings of the 'expected' and 'not-so-expected' online product categories to launch their online business venture. To help their decision, the survey asked an open ended question to the respondents to request specific products from the online retailers. Out of 424 respondents, $7.7 \%$ requested for medicine, about $6.9 \%$ requested for gift, flower and handicraft, $6.8 \%$ want to purchase car accessories, bicycle and spare parts, $3.8 \%$ is looking for sports and movie tickets, $1.4 \%$ need stationary items, $3.6 \%$ is keen to buy eye wear, $1.7 \%$ will be happy to find event managements i.e. wedding and birthday party services, $2.9 \%$ want handbags and $9.8 \%$ want to buy travel tickets, holiday packages and travel accessories online.

This research found trends of Facebook shopping (F-commerce) in Bangladesh. But the abandon rate is high as well due to poor delivery service as one of the reasons. The cause can be that business owners may not be investing in reliable delivery service at these early stages of this growth period. This scenario provides an opportunity to establish on-demand delivery service business to support F-commerce ventures. Such service was not so prominent in online search result during this research. Initiators may find it difficult to attract partners to use their service but it may have sustainable growth as the industry starts to benefit from it.

A quick survey of online stores (both website and Facebook) operating in Bangladesh did not find noticeable use of Skype and Viber as customer care option at the time of this research. It is obvious that Gen Y consumers in Bangladesh are keen to use voice over internet services which does not cost call credit. Thus business owners may become benefited if they introduce such services in their customer care. Harnessing the advantages of quick and timely customer service using social media is a must as well.

\section{Limitations and Further Research}

This study and the outcomes are not without its limitations which need to be discussed to recommend follow-on research. First, the demography of the survey population. Most of the participants are either studying at one of the most prestigious private university in Bangladesh or related to the student. Typically these groups are medium to high achievers in their academic life with access to adequate fund to facilitate use of technology (smartphone, laptop, high speed internet). Conducting the survey on Gen Y with different facility and background may alter some of the findings. For example, Gen Y may not be responsible for a family thus doing grocery shopping and purchasing furniture is at the bottom of their wish list. Second, the geographic location of the participants. They are living and working in the capital city of Bangladesh where access to technology and internet is the best in the country. People from other cities may have different expectations from online retailers depending on the availability of certain product at their location. Third, the unavailability of reference data. This 
research is first of its kind in a rapidly growing online market, and the landscape and demand may follow that trend as well. This very limitation calls for further research on this agenda. Scholars with local market research experience may start to extend on this research and find new insight into the consumer expectations. The findings should assist firms to meet consumer demand in a challenging market and increase profitability by satisfying customers (Lun, Shang, Lai, \& Cheng, 2015). Private organizations with interest should invest in such research.

Other stream of this research can be the assessment of online service industry. Banks, insurance companies and government departments are expanding online in Bangladesh. Organizations need to engage consumers in their development process to customer services as per expectations. Marketers also need to start identifying the difference and similarities in online consumer behaviour. Their findings will assist the online business to reach target consumers in an efficient way. The growth of social media shopping needs to be observed and facilitated as well.

\section{References}

A2i. (2009). Digital Bangladesh Concept Note. Dhaka, Bangladesh: Government of Bangladesh. Retrieved from http://www.a2i.gov.bd/sites/default/files/resource_docs/Digital\%20Bangladesh\%20Concept\%20Note_Final .pdf

Abbasi, M. S., Chandio, F. H., Soomro, A. F., \& Shah, F. (2011). Social influence, voluntariness, experience and the internet acceptance: An extension of technology acceptance model within a south-Asian country context. Journal of Enterprise Information $\quad$ Management, $24(1), \quad 30-52$. http://dx.doi.org/10.1108/17410391111097410

Ahmad, I., \& Agrawal, A. M. (2014). Major impediments in the growth of B2B e-commerce market in Kuwait: An empirical study from industrial perspective. European Journal of Business and Management, 6(17), 19-26.

Aksoy, L., van Riel, A., Kandampully, J., Bolton, R. N., Parasuraman, A., Hoefnagels, A., ... Komarova Loureiro, Y. (2013). Understanding Generation Y and their use of social media: A review and research agenda. Journal of Service Management, 24(3), 245-267. http://dx.doi.org/10.1108/09564231311326987

Al Noor, M., \& Arif, R. B. (2011). Adoption of B2B e-commerce by the SMEs in Bangladesh. Innovative Systems Design and Engineering, 2(6), 48-59.

Alexa. (2015). Top sites in Bangladesh. Retrieved 3 May, 2015, from http://www.alexa.com/topsites/countries/BD

Al-Sedrani, A., \& Al-Khalifa, H. S. (2012). Design considerations for the localization of Arabic e-commerce websites. Paper presented at the Digital Information Management (ICDIM), 2012 Seventh International Conference on. http://dx.doi.org/10.1109/icdim.2012.6360094

Valentine, B. D., \& Powers, L. T. (2013). Generation Y values and lifestyle segments. Journal of Consumer Marketing, 30(7), 597-606. http://dx.doi.org/10.1108/JCM-07-2013-0650

Badran, M. F. (2013). Young people and the digital divide in Egypt: An empirical study. Eurasian Economic Review, 1-28. http://dx.doi.org/10.1007/s40822-014-0008-z

Bakewell, C., \& Mitchell, V. W. (2003). Generation Y female consumer decision-making styles. International Journal of Retail \& Distribution Management, http://dx.doi.org/10.1108/09590550310461994

Bank, T. W. (2015). Bangladesh development update. Bangladesh: The World Bank. Retrieved from http://documents.worldbank.org/curated/en/2015/04/24323972/bangladesh-development-update-april-2015

Bhattacharya, S., \& Mishra, B. B. (2015). Evolution, growth and challenges in e-commerce industry: A case of India. Sumedha Journal of Management, 4(1), 45.

Cabral, J. (2011). Is generation Y addicted to social media. The Elon Journal of Undergraduate Research in Communications, 2(1), 125.

Chaffey, D. (2007). E-business and e-commerce management: Strategy, implementation and practice. Pearson Education.

Chen, G., \& Rasmussen, S. (2014). Kash Bangladesh: A fast start for mobile financial services.

Cheung, C. M., \& Lee, M. K. (2012). What drives consumers to spread electronic word of mouth in online 
$\begin{array}{lllll}\text { consumer-opinion platforms. Decision Support } & \text { Systems, }\end{array}$ http://dx.doi.org/10.1016/j.dss.2012.01.015

Chu, S. C., \& Choi, S. M. (2011). Electronic word-of-mouth in social networking sites: A cross-cultural study of the United States and China. Journal of Global Marketing, 24(3), 263-281. http://dx.doi.org/10.1080/08911762.2011.592461

CIA. (2014, 20 May, 2015). The world factbook-Bangladesh. The World Factbook. Retrieved 11 May, 2015, from https://www.cia.gov/library/publications/the-world-factbook/geos/bg.html

ComJagat. (2014). E-commerce directory 2014. Retrieved 7 May, 2015, from http://e-commercefair.com/wp-content/uploads/2014/07/E-Commerce-Directory.pdf

De Vries, N. J., \& Carlson, J. (2014). Examining the drivers and brand performance implications of customer engagement with brands in the social media environment. Journal of Brand Management, 21(6), 495-515. http://dx.doi.org/10.1057/bm.2014.18

Deshmukh, S. P., Deshmukh, P., \& Thampi, G. (2013). Transformation from e-commerce to m-commerce in Indian context. International Journal of Computer Science Issues, 10(4), 55-60.

Duggan, M., \& Brenner, J. (2013). The demographics of social media users, 2012 (Vol. 14). Pew Research Center's Internet \& American Life Project Washington, DC.

Eid, M. I. (2011). Determinants of e-commerce customer satisfaction, trust, and loyalty in Saudi Arabia. Journal of Electronic Commerce Research, 12(1), 78-93.

Einav, L., Levin, J., Popov, I., \& Sundaresan, N. (2014). Growth, adoption, and use of mobile e-commerce. The American Economic Review, 104(5), 489-494. http://dx.doi.org/10.1257/aer.104.5.489

eMarketer. (2011, 26 July). Brands and consumers create value together - Collaborating from idea generation to $\begin{array}{lllll}\text { customer } & \text { service } & \text { Retrieved } & \text { March, } & \text { 2015, }\end{array}$ http://www.emarketer.com/Article.aspx?R=1008511\&dsNav=Rpp:25,Ro:6,N:1125

Fang, Y., Qureshi, I., Sun, H., McCole, P., Ramsey, E., \& Lim, K. H. (2014). Trust, satisfaction, and online repurchase intention: The moderating role of perceived effectiveness of e-commerce institutional mechanisms. Mis Quarterly, 38(2), 407-427.

Faroqi, M. G. (2015). An assessment of e-government case study on Union Digital Centres (UDC) in Bangladesh. Australian Journal of Sustainable Business and Society, 1(1).

Fisher, G., \& Kotha, S. (2014). HomeGrocer.com: Anatomy of a failure. Business Horizons, 57(2), 289-300. http://dx.doi.org/10.1016/j.bushor.2013.12.002

Forbs. (2014, 30 Sept). Amazon's CEO believes in India's growth story. Retrieved 3 Jan, 2015, from http://www.forbes.com/sites/greatspeculations/2014/09/30/amazons-ceo-believes-in-indias-growth-story/

Garza, J. (2015, 9 January). Two silicon valley leaders join forces to launch and fund technology companies in Bangladesh. Retrieved 17 May, 2015, from http://fi.co/posts/12481

Ghosh, D. (2014). Why indian e-retailing market is still a partly success and a partly failure story. J. Account Mark, 3(113), 2. http://dx.doi.or/10.4172/2168-9601.1000113

Hasan, M. M., \& Islam, M. R. (2013). Assessing service quality of mobile money transfer in Bangladesh: A case study on bKash. International Journal of Innovative Research and Development, 2(7).

Heidenreich, S., \& Handrich, M. (2015). Adoption of technology-based services: The role of customers' willingness to co-create. Journal of Service Management, 26(1), 44-71. http://dx.doi.org/10.1108/JOSM-03-2014-0079

Herter, M., dos Santos, C. P., \& Costa, D. (2015). Man, i shop like a woman! Effects of gender and emotions on consumer shopping outcomes and perceptions of retail environments. Ideas in Marketing: Finding the New and Polishing the Old (pp. 34-34): Springer.

Islam, M. A., Khan, M. A., Ramayah, T., \& Hossain, M. M. (2011). The adoption of mobile commerce service among employed mobile phone users in Bangladesh: Self-efficacy as a moderator. International Business Research, 4(2), 80. http://dx.doi.org/10.5539/ibr.v4n2p80

Islam, M. Z. (2014, 4 April). BTCL cuts bandwidth price by 42\%. Retrieved 2 May, 2015, from http://www.dhakatribune.com/regulation/2014/apr/04/btcl-cuts-bandwidth-price-42 
Karnik, M., Oakley, I., Venkatanathan, J., Spiliotopoulos, T., \& Nisi, V. (2013). Uses \& gratifications of a facebook media sharing group. Paper presented at the Proceedings of the 2013 conference on Computer supported cooperative work. http://dx.doi.org/10.1145/2441776.2441868

Khan, M., Hossain, S., Hasan, M., \& Clement, C. K. (2012). Barriers to the Introduction of ICT into Education in Developing Countries: The Example of Bangladesh. Online Submission, 5(2), 61-80.

KPMG. (2012). Bangladesh beckons: An emerging IT/ITeS outsourcing destination. Bangladesh: KPMG International. Retrieved from https://www.kpmg.com/.../UNITC\%20KPMG\%20Whitepaper.pdf

Kramer, A. D. (2012). The spread of emotion via Facebook. Paper presented at the Proceedings of the SIGCHI Conference on Human Factors in Computing Systems. http://dx.doi.org/10.1145/2207676.2207787

Kshetri, N., \& Dholakia, N. (2005). E-commerce patterns in South Asia: A look beyond economics. Journal of Asia-Pacific Business, 6(3), 63-79. http://dx.doi.org/10.1300/J098v06n03_04

Laan, D. J. V. D. (2015). Online grocery retailing. Retrieved 3 May, 2015, from $\mathrm{http} / / /$ retaileconomics.com/online-grocery-retailing/

Laudon, K. C., \& Traver, C. G. (2007). E-commerce. Pearson/Addison Wesley.

Lazarevic, V. (2012). Encouraging brand loyalty in fickle generation Y consumers. Young Consumers, 13(1), 45-61. http://dx.doi.org/10.1108/17473611211203939

Lucini, B. A., \& Hatt, T. (2014). Country overview: Bangladesh. London: GSMA Intelligence Retrieved from https://gsmaintelligence.com/research/?file=140820-bangladesh.pdf\&download

Lun, Y. V., Shang, K. C., Lai, K. H., \& Cheng, T. (2015). Examining the influence of organizational capability in innovative business operations and the mediation of profitability on customer satisfaction: An application in intermodal transport operators in Taiwan. International Journal of Production Economics. http://dx.doi.org/10.1016/j.ijpe.2015.02.019

Mangold, W. G., \& Faulds, D. J. (2009). Social media: The new hybrid element of the promotion mix. Business Horizons, 52(4), 357-365. http://dx.doi.org/10.1016/j.bushor.2009.03.002

Mata, F. J., \& Quesada, A. (2014). Web 2.0, social networks and E-commerce as marketing tools. Journal of Theoretical and Applied Electronic Commerce Research, 9(1), 56-69. http://dx.doi.org/10.4067/S0718-18762014000100006

McKinsey. (2014). Offline and falling behind: Barriers to Internet adoption.

Navis, C., Fisher, G., Raffaelli, R., Glynn, M. A., \& Watkiss, L. (2012). The market that wasn't: The non-emergence of the online grocery category. Paper presented at the Proceedings of the New Frontiers in Management and Organizational Cognition Conference.

Noble, S. M., Haytko, D. L., \& Phillips, J. (2009). What drives college-age generation Y consumers? Journal of Business Research, 62(6), 617-628. http://dx.doi.org/10.1016/j.jbusres.2008.01.020

Nyenrode. (2014). ICT sector study Bangladesh: Bridging the gap between Dutch and Bangladeshi ICT sectors. Breukele, Netherlands: Nyenrode Business Universiteit. Retrieved from http://www.basis.org.bd/resource/ICT\%20Sector\%20Study\%20Bangladesh.pdf

Ordun, G. (2015). Millennial (Gen Y) consumer behavior their shopping preferences and perceptual maps associated with brand loyalty. Canadian Social Science, 11(4). http://dx.doi.org/10.3968\%2F6697

Palfrey, J., \& Gasser, U. (2013). Born digital: Understanding the first generation of digital natives. Basic Books.

Priyo, M. I., Scheresberg, C. D. B., Ali, J., Abbas, S., Khan, H. U., \& Rashid, Z. (2015). Framework of critical success factors for growth of mobile money platforms in emerging markets. Paper presented at the Global Conference on Business \& Finance Proceedings.

PwC. (2015). Retail categories: How consumers shop. Total Retail. Retrieved 23 April, 2015, from http://www.pwc.com/gx/en/retail-consumer/retail-consumer-publications/global-multi-channel-consumer-s urvey/retail-subsectors.jhtml

Randall, R., \& Bhalla, G. (2014). How to plan and manage a project to co-create value with stakeholders. Strategy \& Leadership, 42(2), 19-25. http://dx.doi.org/10.1108/SL-01-2014-0006

Reynolds, L., Bush, E. C., \& Geist, R. (2008). The gen Y imperative. Communication World, 25(3), 19-22.

Rideout, V. (2013). Zero to eight: Children's media use in America 2013. A Common Sense Media research 
study.

Robenhagen, S., Shahrukh, S. A., \& Taufiq, S. (2014). ICT and e-commerce booming in Bangladesh. Bangladesh: Embassy of Denmark Retrieved from http://bangladesh.um.dk/en/ /media/Bangladesh/Documents/Teaser\%20on\%20e-commerce\%20final.pdf

Roberts, D. F., \& Foehr, U. G. (2008). Trends in media use. The Future of Children, 18(1), 11-37. http://dx.doi.org/10.1353/foc.0.0000

Ryan, T., \& Xenos, S. (2011). Who uses Facebook? An investigation into the relationship between the big five, shyness, narcissism, loneliness, and Facebook usage. Computers in Human Behavior, 27(5), 1658-1664. http://dx.doi.org/10.1016/j.chb.2011.02.004

Selwyn, N. (2012). Making sense of young people, education and digital technology: The role of sociological theory. Oxford Review of Education, 38(1), 81-96. http://dx.doi.org/10.1080/03054985.2011.577949

Sharma, R. K., \& Mishra, S. K. (2012). E Commerce in India-The way to shop. International Journals of Marketing and Technology, 2(2), 298-313.

Sisson, R., \& Rose, L. E. (1991). War and secession: Pakistan, India, and the creation of Bangladesh. Univ of California Press.

Spiggle, S. (1994). Analysis and interpretation of qualitative data in consumer research. Journal of Consumer Research, 491-503. http://dx.doi.org/10.1086/209413

Wang, Q., Woo, H. L., Quek, C. L., Yang, Y., \& Liu, M. (2012). Using the facebook group as a learning management system: An exploratory study. British Journal of Educational Technology, 43(3), 428-438. http://dx.doi.org/10.1111/j.1467-8535.2011.01195.x

Wei, J. (2012). Great inventions that changed the world. John Wiley \& Sons. http://dx.doi.org/10.1002/9781118342749

Weisberg, J., Te'eni, D., \& Arman, L. (2011). Past purchase and intention to purchase in e-commerce: The mediation of social presence and trust. Internet Research, 21(1), 82-96. http://dx.doi.org/10.1108/10662241111104893

WHOis.net. (2015). Who is lookup-Domain names search, registration and availability. Retrieved 1 May, 2015, from https://www.whois.net/

Witell, L., Kristensson, P., Gustafsson, A., \& Löfgren, M. (2011). Idea generation: Customer co-creation versus traditional market research techniques. Journal of Service Management, 22(2), 140-159. http://dx.doi.org/10.1108/09564231111124190

WorldBank. (2014). Implementation Status \& Results - Bangladesh: Leveraging ICT Growth, Employment and Governance Project (P122201). (ISR16728). The World Bank Retrieved from http://www.worldbank.org/projects/P122201/leveraging-ict-governance-growth-employment-project?lang= en

Zhang, B., Carpenter, J. M., \& Brosdahl, D. J. (2011). Shopping orientations and retail format choice among generation Y apparel shoppers. Journal of Textile and Apparel, Technology and Management, 7(1).

\section{Notes}

Note 1.

http://bangladoot.se/IT\%20Delegation\%20Visit\%20to\%20Bd/Bangladesh\%20IT\%20Industry\%20Overview_3.2. 2014.pdf

Note 2. http://www.dhakatribune.com/business/2015/jan/12/bsccl-cut-wholesale-bandwidth-price-33

Note 3. http://www.dhakatribune.com/regulation/2014/apr/04/btcl-cuts-bandwidth-price-42

Note 4. http://www.bd.airtel.com/package.php

Note 5. http://www.grameenphone.com/business/enterprise-solutions/mobile-office/3g-packages

Note 6. http://www.teletalk.com.bd/cpoint/3G/3g_data_plan.php

Note 7. https://www.robi.com.bd/en/internet-packages

Note 8. http://www.banglalink.com.bd/en/services/banglalink-internet/packages/ 
Note 9. http://kenstechtips.com/index.php/the-uks-6-best-value-smartphone-sim-only-tariffs-with-internet-access

Note 10. https://www.globalgig.com/au/en/press

Note 11. http://www.vodafone.com.au/personal/mobile-internet/on-your-phone/plans

Note 12. http://trak.in/tags/business/2014/02/26/3g-data-plans-comparison/

\section{Copyrights}

Copyright for this article is retained by the author(s), with first publication rights granted to the journal.

This is an open-access article distributed under the terms and conditions of the Creative Commons Attribution license (http://creativecommons.org/licenses/by/3.0/). 